\title{
Crisis Management and Economic Growth in the Eurozone
}

Paul De Grauwe and Yuemei Ji

\subsection{Introduction}

Since the financial crisis of 2007-8 most developed countries have been unable to return to their pre-crisis growth path. Nowhere in the developed world is this more visible than in the Eurozone. We show this in Figure 2.1, in which we compare the evolution of real G.D.P. in the Eurozone with real G.D.P. in the U.S.A. and in the E.U.-countries not belonging to the Eurozone (E.U.10). The difference is striking. Prior to the financial crisis, the Eurozone real G.D.P. was on a slower growth path than in the U.S.A. and in E.U.10. Since the financial crisis of 2008, the divergence has increased even further. Real G.D.P. in the Eurozone stagnated and in 2014 was even lower than in 2008. In the U.S.A. and E.U.10 one observes (after the dip of 2009) a relatively strong recovery. Admittedly, this recovery is below the potential growth path of these countries (see Summers, 2014), but is much more pronounced than in the Eurozone where stagnation prevailed. Note also that there was a recovery in the Eurozone from 2009 to 2011, and that from 2012 to 2013 the Eurozone experienced a double-dip recession.

What is it that makes the Eurozone such a pronounced island of stagnation in the developed world? This is the question that we want to analyze in this chapter.

\subsection{Eurozone Stagnation: Supply or Demand Problem?}

The policy response to the sovereign debt crisis has very much been influenced by a supply side story of the origins of the low growth in the Eurozone. 
OUP UNCORRECTED PROOF-FIRST PROOF, 8/3/2016, SPi

Crisis Management and Economic Growth in the Eurozone

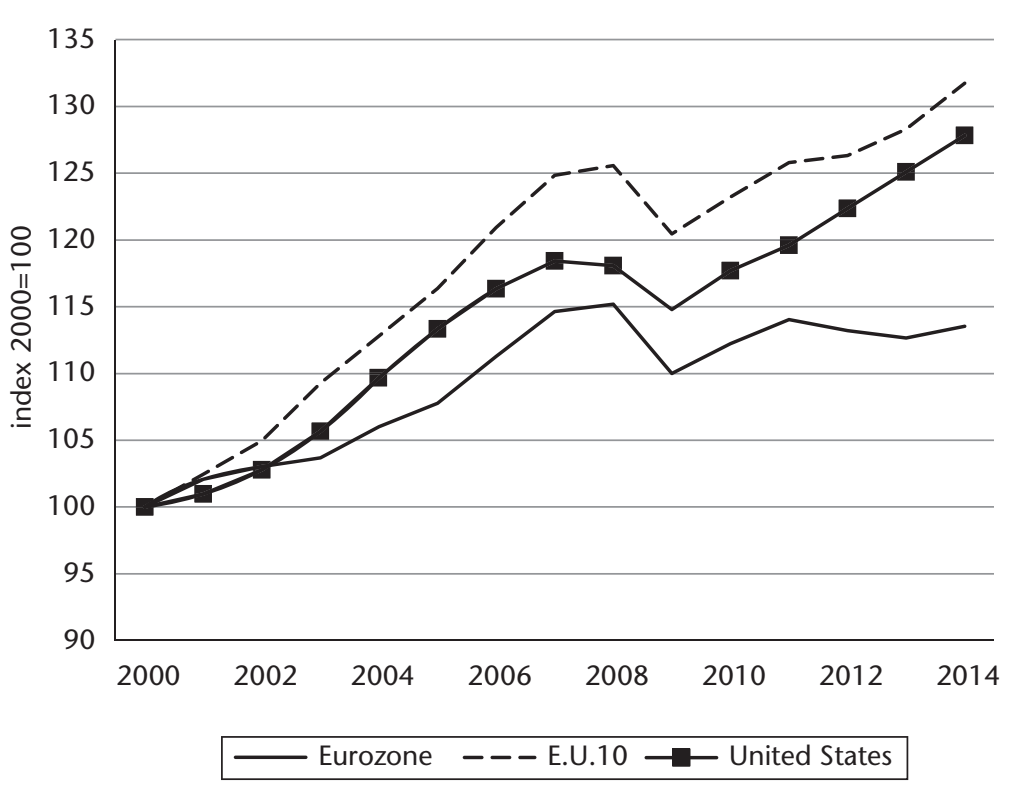

Figure 2.1. Real G.D.P. (prices of 2010) in Eurozone, E.U.10, and U.S.A. Source: European Commission, Ameco database.

In this view, low growth is the result of structural rigidities, that is of a lack of flexibility in the way the supply side of the economy works. Labour markets are rigid, preventing demand and supply of labour from reaching equilibrium. As a result of these rigidities, production remains below its potential. Similarly, the goods markets are subject to price rigidities and other imperfections that also reduce potential output. Policies that eliminate these imperfections will increase potential output, so goes this story that has become the mainstream view among policymakers in Europe.

Implicit in this view is that the increase in potential output will automatically lead to an increase in realized output. Put differently, Say's Law, according to which supply creates its own demand, is implicitly assumed. Thus, policies that improve the supply side through structural reforms will automatically lead to more demand and thus to more production. The demand side of the economy adjusts automatically to the supply side.

From Brussels, Frankfurt, and Berlin we have been hearing incessantly that structural reforms are the key to economic recovery and higher growth rates. Making labour and output markets more flexible is the only way to boost economic growth in the Eurozone in a sustainable way, so we are told by European policymakers. This view has been very influential and has led countries into programmes of structural reforms of labour and product markets. 


\section{OUP UNCORRECTED PROOF-FIRST PROOF, 8/3/2016, SPi}

Paul De Grauwe and Yuemei Ji

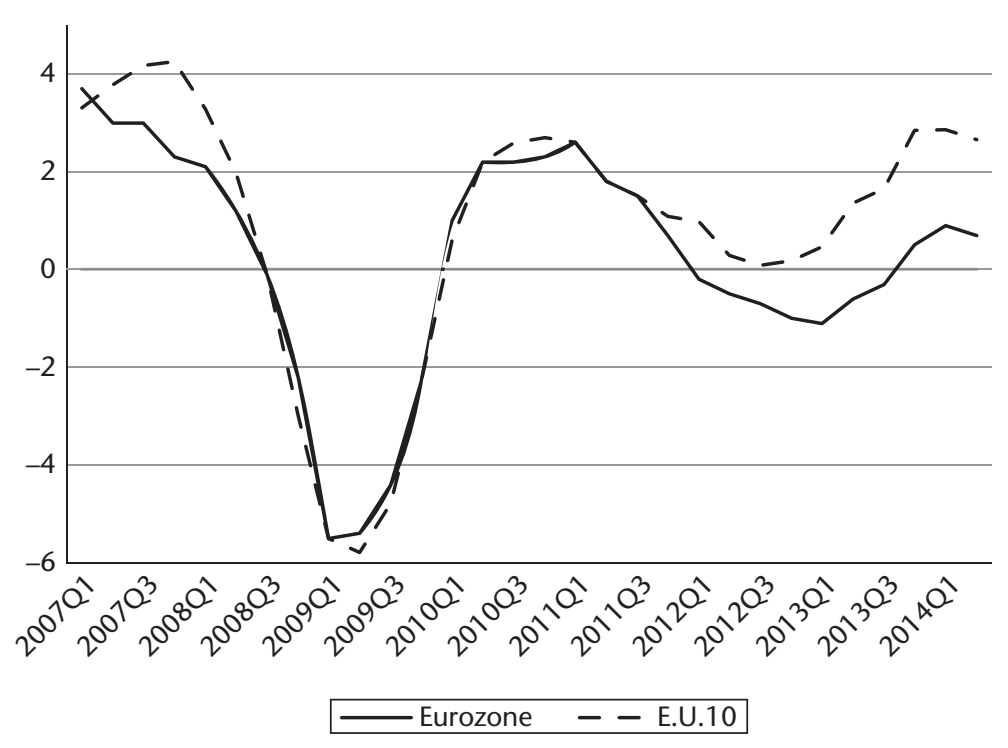

Figure 2.2. Growth G.D.P. in Eurozone (E.U.18) and E.U.10 (per cent). Source: Eurostat.

A quick look at Figure 2.2 makes us sceptical of this view. We observe that since 2010-11 the E.U.10 has experienced a strong recovery, whereas the Eurozone got caught in stagnation. Prior to those years, the Eurozone and the E.U.10 experienced similar movements of G.D.P. growth. If stagnation in the Eurozone since the start of the sovereign debt crisis is the result of structural rigidities, it is difficult to understand why the same structural rigidities prevented the Eurozone from engineering an equally quick recovery from the Great Recession of 2008-9 as the E.U.10.

All this of course is only suggestive evidence. A more systematic empirical analysis is necessary to find out how important structural rigidities in the labour and product markets are for economic growth. To analyze this question we perform an econometric analysis of the factors that affect economic growth. We will rely on the theory and the econometrics of economic growth (see, e.g., Barro and Sala-i-Martin, 2003; Acemoglu, 2009).

\subsection{Structural Rigidities and Growth: An Econometric Analysis}

Since Robert Solow's seminal contribution, modern economic growth theory has identified a number of fundamental variables that drive the economic growth process. These variables are population growth, physical and human capital accumulation, and technological progress (the residual in Solow's 
Crisis Management and Economic Growth in the Eurozone

growth model). Recent theoretical contributions have highlighted the importance of institutions as deep variables that influence the process of capital accumulation and technological progress (productivity growth). Influential contributions are Barro and Sala-i-Martin (2003) and Acemoglu and Robinson (2012).

There are many institutional features that can influence the economic growth process. The econometric literature has put a lot of emphasis on political institutions (nature of democracy, transparency of political system, rule of law, etc.) that affect the dynamics of physical and human capital accumulation and technological progress, and through this channel economic growth. The flexibility of labour and capital markets (or the lack thereof) is part of the institutional characteristics of countries that can affect economic growth. Surprisingly, relatively little importance has been given to these features in traditional econometric analyses of econometric growth. ${ }^{1}$ In this section we present an econometric growth model using indicators of the degree of flexibility in labour and product markets as one of the institutions that can facilitate capital accumulation and productivity growth.

The study is limited in that it focuses on flexibility in labour and product markets and not the many other institutions that have been identified in the econometric growth literature (see Aghion and Howitt, 1998; Barro and Sala-i-Martin, 2003; Acemoglu, 2009). One institutional feature we introduce to the analysis is the quality of public governance. We use the World Bank's index of government effectiveness. We hope at a later stage to integrate more institutional variables into the analysis.

Our study is limited in another sense. We restrict our econometric analysis to O.E.C.D. countries. The main reason is that the indices of labour and output market flexibility in which we are interested have been constructed by the O.E.C.D. for the O.E.C.D.-member countries. We are not aware of similar indicators of labour and product market flexibility for other countries.

The econometric model is specified as follows:

$$
\begin{aligned}
y_{i, t}= & a_{i}+\beta I_{i, t}+\mu H_{i, t}+\theta E P L_{i, t}+\lambda A g e_{i, t}+\rho P M_{i, t}+\sigma G E_{i, t} \\
& +\gamma R_{i, t}+\delta G_{i, t}+\varepsilon_{i, t}
\end{aligned}
$$

where $y_{i, t}=$ growth rate of per capita G.D.P. in year $t$ in country $i$. This way of defining the growth rate is equivalent to explaining the growth rate of G.D.P. by population growth while assuming that the effect of population growth on G.D.P. growth has a unitary elasticity; $I_{i, t}=$ the ratio of investment (private + public) to G.D.P. in year $t$ in country $i$. This measures the process

1 There have been quite some empirical studies of the effect of structural reforms on economic growth. These have mainly been performed by official institutions such as the OECD, the European Commission and the ECB. We review these in Section 2.4. 
OUP UNCORRECTED PROOF-FIRST PROOF, 8/3/2016, SPi

Paul De Grauwe and Yuemei Ji

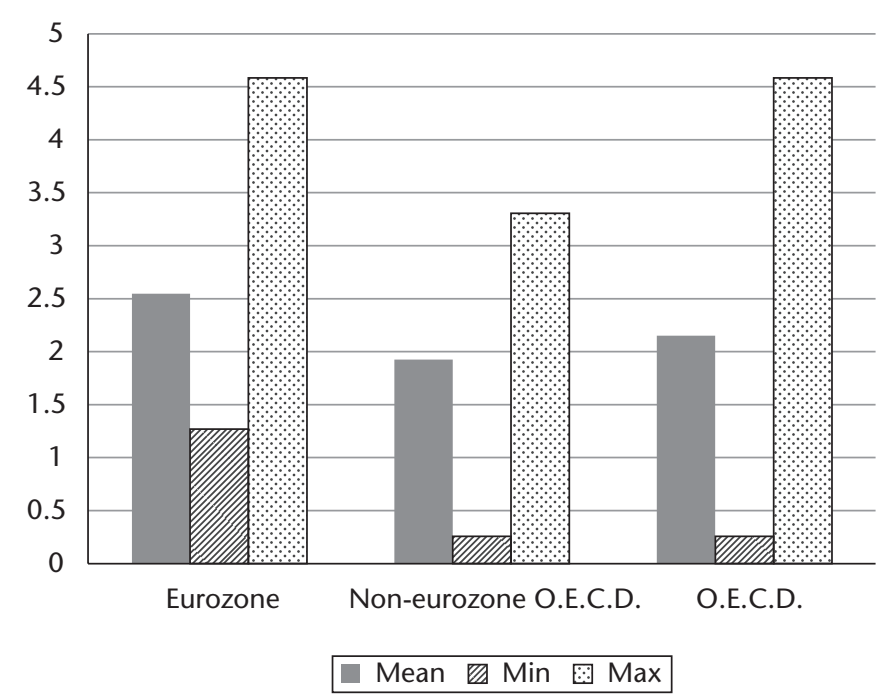

Figure 2.3. Employment Protection Legislation Index (mean 1998-2013).

Source: O.E.C.D. and authors' own calculation.

of capital accumulation on economic growth; $H_{i, t}=$ the proportion of the population with a tertiary education. This variable represents human capital accumulation. We expect it to have a positive effect on economic growth; $E P L_{i, t}=$ the employment protection legislation (E.P.L.) index as measured by the O.E.C.D. (in year $t$ and country i). It is generally agreed that more intense employment protection legislation makes the labour market more rigid. Making firing more expensive also makes firms more reluctant to hire. As a result, employment growth will be curtailed and so will economic growth. Thus one expects a negative effect of E.P.L. on economic growth. We show the mean E.P.L. index in the O.E.C.D. countries in Figure 2.3; $A g e_{i, t}=$ this is the average effective retirement age in year $t$ in country $i$. According to accepted wisdom a country that increases the retirement age of the working population should experience more economic growth; $P M_{i, t}=$ the product market regulation (P.M.R.) index as computed by the O.E.C.D. According to conventional wisdom more product market rigidities have a negative effect on economic growth. We show the mean P.M.R. index in the O.E.C.D. countries in Figure 2.4; $G E_{i, t}=$ the government effectiveness index as computed by the World Bank. More effective government should boost economic growth.

We have added two other control variables that are often introduced in econometric growth equations, that is the real effective exchange rate, ${ }^{2} R_{i, t}$,

2 This is measured by the effective exchange rate of country $i$ in year $t$ corrected for the ratio of consumer prices in country $i$ versus the trading partners of country $i$. 


\section{OUP UNCORRECTED PROOF-FIRST PROOF, 8/3/2016, SPi}

Crisis Management and Economic Growth in the Eurozone

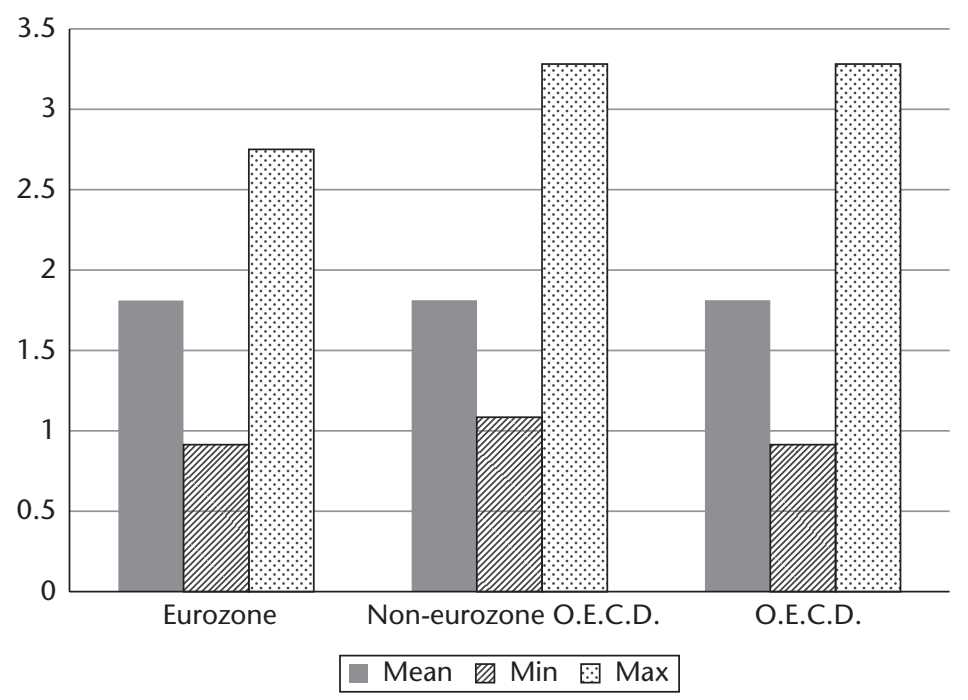

Figure 2.4. Product Market Regulation Index (mean 1998-2013). Source: O.E.C.D. and authors' own calculation.

and government consumption as a per cent of G.D.P. The former should have a negative effect on economic growth, that is an overvalued currency should reduce economic growth; the latter is often assumed to have a negative effect on G.D.P. growth. $a_{i}$ is the fixed country effect measuring time invariant idiosyncrasies of countries. An important one is the initial level of per capita income. Our empirical analysis relies on the fixed effect model.

The model was estimated for the O.E.C.D. countries. One problem we encountered is that the sample of member-countries of the O.E.C.D. has changed over time. Prior to 1993 the central European countries were not members. Therefore, we estimate the model first for the smaller group of O.E.C.D.-countries (called advanced economies) that were members prior to 1993. This estimation is over the sample period 1985-2013. Then we estimate the model for the full sample of countries but over a shorter time period, that is 1998-2013. We also estimate one specification without a dummy for the financial crisis (starting in 2008) and one with such a dummy.

The results are presented in Table 1 (the sources of the data are presented in Appendix 2.1). These results lend themselves to the following interpretation.

First, the investment ratio has the expected positive sign and is significant for the O.E.C.D. countries as a whole. Second, our index of human capital (the proportion of the population with tertiary education) has a strong and significantly positive effect on economic growth. Thus the traditional fundamental variables of economic growth, and physical and human capital accumulation are important in driving economic growth. 
OUP UNCORRECTED PROOF-FIRST PROOF, 8/3/2016, SPi

\section{Paul De Grauwe and Yuemei Ji}

The most striking aspect of our results is the finding that the structural measures of the labour and product market rigidities do not seem to have any influence on the growth rate of G.D.P. per capita. The O.E.C.D. employment protection legislation index even appears to have a systematically positive effect on growth in the full sample of the advanced economies. This is not found in the shorter sample of all O.E.C.D.-countries, where this effect is not significantly different from zero.

There is a possibility that labour market protection and product market regulations affect economic growth indirectly through their effect on investment. One should not exclude the possibility that rigidities in labour and product markets have a negative effect on investment, and through this channel reduce economic growth. To test for this hypothesis, we regressed investment (as a per cent of G.D.P.) on our indices of labour and product market rigidities, together with a number of control variables. We show the results in Appendix 2.2. It appears that we can reject the hypothesis that labour market and product market rigidities are associated with lower investment. In fact, in the case of labour market protection we find a positive association, that is higher labour market protection is associated with higher investment.

Our conclusion is that employment protection is of no visible importance for economic growth. This may seem surprising. The Brussels-Frankfurt consensus has stressed that employment protection has a negative effect on hiring, and subsequently reduces prospects for growth. This may be true but there is another phenomenon that may more than compensate the positive effect of flexibility on economic growth. In economies in which employment protection is weak, the incentives for firms to invest in its labour force are weak. When turnover is high firms are unlikely to invest in personnel who are likely to quit early. In addition, employees that can be fired quickly have equally weak incentives to invest in firm-specific skills. As a result, labour productivity is negatively affected. More generally, the quality of human capital will be low.

One must also take into account that reverse causality may be at work, biasing the results. This reverse causality runs as follows. In countries with high growth, there is a high demand for labour protection. Workers and their representatives are strong and are pushing for legislation to provide strong employment protection. As a result, we will observe that high growth is correlated with employment protection.

To correct for this reverse causality, we used an instrumental variable method. We selected two instruments: the lagged E.P.L. index and the ideological composition of the government along the scale right to left (for a description, see Appendix 2.1). This takes the view that employment protection is positively correlated with the ideological composition of govern- 
OUP UNCORRECTED PROOF-FIRST PROOF, 8/3/2016, SPi

Crisis Management and Economic Growth in the Eurozone

Table 2.1. Estimation results (O.L.S.)

\begin{tabular}{|c|c|c|c|c|}
\hline & $\begin{array}{c}(1) \\
\text { Advanced } \\
\text { economies } \\
\text { 1985-2013 }\end{array}$ & $\begin{array}{c}(2) \\
\text { Advanced } \\
\text { economies } \\
\text { 1985-2013 }\end{array}$ & $\begin{array}{c}(3) \\
\text { O.E.C.D. } \\
\text { economies } \\
\text { 1998-2013 }\end{array}$ & $\begin{array}{c}(4) \\
\text { O.E.C.D. } \\
\text { economies } \\
\text { 1998-2013 }\end{array}$ \\
\hline Investment/G.D.P. & $\begin{array}{c}0.131 \\
(0.081)\end{array}$ & $\begin{array}{c}0.083 \\
(0.076)\end{array}$ & $\begin{array}{l}0.337^{* * *} \\
(0.119)\end{array}$ & $\begin{array}{l}0.346^{* * *} \\
(0.120)\end{array}$ \\
\hline Proportion of tertiary education & $\begin{array}{l}1.739^{* * *} \\
(0.139)\end{array}$ & $\begin{array}{l}1.802^{* * *} \\
(0.174)\end{array}$ & $\begin{array}{l}1.400^{* * *} \\
(0.157)\end{array}$ & $\begin{array}{l}1.472^{* * *} \\
(0.174)\end{array}$ \\
\hline Real effective exchange rate & $\begin{array}{c}-0.040^{* * *} \\
(0.014)\end{array}$ & $\begin{array}{c}-0.034^{* *} \\
(0.012)\end{array}$ & $\begin{array}{l}-0.044^{* * *} \\
(0.015)\end{array}$ & $\begin{array}{c}-0.046^{* * *} \\
(0.014)\end{array}$ \\
\hline Working population growth & $\begin{array}{r}-0.259 \\
(0.391)\end{array}$ & $\begin{array}{r}-0.357 \\
(0.335)\end{array}$ & $\begin{array}{c}-0.640^{* *} \\
(0.302)\end{array}$ & $\begin{array}{c}-0.939^{* * *} \\
(0.317)\end{array}$ \\
\hline Government consumption/G.D.P. & $\begin{array}{c}-0.870^{* * *} \\
(0.134)\end{array}$ & $\begin{array}{c}-0.633^{* * *} \\
(0.130)\end{array}$ & $\begin{array}{c}-0.759^{* * *} \\
(0.155)\end{array}$ & $\begin{array}{c}-0.500^{* * *} \\
(0.156)\end{array}$ \\
\hline Effective retirement age & $\begin{array}{c}-0.135 \\
(0.152)\end{array}$ & $\begin{array}{c}0.107 \\
(0.155)\end{array}$ & $\begin{array}{r}-0.122 \\
(0.197)\end{array}$ & $\begin{array}{c}0.103 \\
(0.179)\end{array}$ \\
\hline Government effectiveness & $\begin{array}{l}2.002^{* *} \\
(0.911)\end{array}$ & $\begin{array}{c}1.414 \\
(0.984)\end{array}$ & $\begin{array}{l}2.513^{* *} \\
(0.962)\end{array}$ & $\begin{array}{l}1.952^{* *} \\
(0.878)\end{array}$ \\
\hline Crisis period & & $\begin{array}{c}-1.526^{* * *} \\
(0.272)\end{array}$ & & $\begin{array}{c}-2.142^{* * *} \\
(0.391)\end{array}$ \\
\hline Employment protection & $\begin{array}{l}3.140^{* * *} \\
(0.779)\end{array}$ & $\begin{array}{l}2.383^{* * *} \\
(0.748)\end{array}$ & $\begin{array}{r}-0.470 \\
(2.932)\end{array}$ & $\begin{array}{c}-0.853 \\
(2.884)\end{array}$ \\
\hline Product market protection & & & $\begin{array}{c}0.484 \\
(0.546)\end{array}$ & $\begin{array}{r}-0.989 \\
(0.605)\end{array}$ \\
\hline Observations & 409 & 409 & 457 & 457 \\
\hline R-squared & 0.396 & 0.430 & 0.297 & 0.344 \\
\hline Number of countries & 24 & 24 & 32 & 32 \\
\hline
\end{tabular}

Robust standard errors in parentheses.

*** $\mathrm{p}<0.01$, ** $\mathrm{p}<0.05, * \mathrm{p}<0.1$.

Advanced economy: Australia, Austria, Belgium, Canada, Denmark, Finland, France, Germany, Greece, Ireland, Italy, Japan, South Korea, Luxemburg, Netherlands, New Zealand, Norway, Portugal, Spain, Sweden, Switzerland, U.K., U.S.A.

Regression: fixed effect module.

ments, that is more leftist governments push for more employment protection. The results are presented in Table 2.2. We observe that the strongly positive effect of employment protection on growth disappears. We now find that employment protection has no significant effects on economic growth.

The same conclusion holds for product market regulations. The coefficients of this variable are never significant. Thus, product market regulations do not seem to matter in the process of economic growth. Again this goes against current mainstream thinking, which has been much influenced by, among others, Aghion et al. (2001), and which stresses that the model of perfect competition with free entry and price flexibility boosts innovation among firms that are close to the technological frontier. There is an older literature, however, going back to Joseph Schumpeter, stressing that innovation, investment, and growth are better promoted in an environment 
OUP UNCORRECTED PROOF- FIRST PROOF, 8/3/2016, SPi

Paul De Grauwe and Yuemei Ji

Table 2.2. Estimation Results: Instrumental Variables

\begin{tabular}{|c|c|c|c|c|c|}
\hline & $\begin{array}{c}(1) \\
\text { Advanced } \\
\text { economies } \\
\text { 1985-2013 }\end{array}$ & $\begin{array}{c}(2) \\
\text { O.E.C.D. } \\
\text { economies } \\
\text { 1998-2013 }\end{array}$ & $\begin{array}{c}(3) \\
\text { O.E.C.D. } \\
\text { economies } \\
\text { 1998-2013 }\end{array}$ & $\begin{array}{c}(4) \\
\text { Advanced } \\
\text { economies } \\
\text { 1998-2013 }\end{array}$ & $\begin{array}{c}(5) \\
\text { Advanced } \\
\text { economies } \\
\text { 1998-2013 }\end{array}$ \\
\hline \multicolumn{6}{|l|}{ Second stage: } \\
\hline Investment G.D.P. ratio & $\begin{array}{c}0.111 \\
(0.091)\end{array}$ & $\begin{array}{l}0.270^{* *} \\
(0.129)\end{array}$ & $\begin{array}{l}0.339^{* *} \\
(0.140)\end{array}$ & $\begin{array}{l}0.192^{* *} \\
(0.095)\end{array}$ & $\begin{array}{l}0.257^{* *} \\
(0.118)\end{array}$ \\
\hline $\begin{array}{l}\text { Tertiary education/total } \\
\text { population }\end{array}$ & $\begin{array}{l}1.798^{* * *} \\
(0.148)\end{array}$ & $\begin{array}{l}1.492^{* * *} \\
(0.160)\end{array}$ & $\begin{array}{l}1.464^{* * *} \\
(0.138)\end{array}$ & $\begin{array}{l}1.456^{* * *} \\
(0.147)\end{array}$ & $\begin{array}{l}1.429^{* * *} \\
(0.127)\end{array}$ \\
\hline Real effective exchange rate & $\begin{array}{l}-0.041^{* * *} \\
(0.011)\end{array}$ & $\begin{array}{l}-0.039^{* * *} \\
(0.013)\end{array}$ & $\begin{array}{l}-0.050^{* * *} \\
(0.015)\end{array}$ & $\begin{array}{l}-0.040^{* * *} \\
(0.012)\end{array}$ & $\begin{array}{l}-0.052^{* * *} \\
(0.015)\end{array}$ \\
\hline Working population growth & $\begin{array}{l}-0.425 \\
(0.331)\end{array}$ & $\begin{array}{l}-0.776^{* * *} \\
(0.299)\end{array}$ & $\begin{array}{l}-0.901^{* * *} \\
(0.311)\end{array}$ & $\begin{array}{l}-0.658^{* *} \\
(0.274)\end{array}$ & $\begin{array}{l}-0.792^{* * *} \\
(0.290)\end{array}$ \\
\hline $\begin{array}{l}\text { Government consumption } \\
\text { G.D.P. ratio }\end{array}$ & $\begin{array}{l}-0.670^{* * *} \\
(0.148)\end{array}$ & $\begin{array}{l}-0.597^{* * *} \\
(0.180)\end{array}$ & $\begin{array}{l}-0.535^{* * *} \\
(0.165)\end{array}$ & $\begin{array}{l}-0.733^{* * *} \\
(0.174)\end{array}$ & $\begin{array}{l}-0.666^{* * *} \\
(0.154)\end{array}$ \\
\hline Real retirement age & $\begin{array}{c}0.170 \\
(0.148)\end{array}$ & $\begin{array}{c}0.080 \\
(0.192)\end{array}$ & $\begin{array}{c}0.085 \\
(0.189)\end{array}$ & $\begin{array}{c}0.192 \\
(0.175)\end{array}$ & $\begin{array}{c}0.189 \\
(0.173)\end{array}$ \\
\hline Government effectiveness & $\begin{array}{c}0.737 \\
(1.019)\end{array}$ & $\begin{array}{l}1.016 \\
(0.961)\end{array}$ & $\begin{array}{c}0.766 \\
(0.932)\end{array}$ & $\begin{array}{c}0.829 \\
(0.991)\end{array}$ & $\begin{array}{c}0.528 \\
(0.946)\end{array}$ \\
\hline Crisis & $\begin{array}{l}-1.595^{* * *} \\
(0.286)\end{array}$ & $\begin{array}{l}-1.771^{* * *} \\
(0.320)\end{array}$ & $\begin{array}{l}-2.142^{* * *} \\
(0.406)\end{array}$ & $\begin{array}{l}-1.415^{* * *} \\
(0.315)\end{array}$ & $\begin{array}{l}-1.740^{* * *} \\
(0.378)\end{array}$ \\
\hline Employment protection & $\begin{array}{r}1.936^{*} \\
(1.069)\end{array}$ & $\begin{array}{l}-1.267 \\
(2.484)\end{array}$ & $\begin{array}{c}-0.784 \\
(2.509)\end{array}$ & $\begin{array}{c}1.101 \\
(1.066)\end{array}$ & $\begin{array}{c}1.608 \\
(1.138)\end{array}$ \\
\hline Product market protection & & & $\begin{array}{r}-0.775 \\
(0.590)\end{array}$ & & $\begin{array}{r}-0.647 \\
(0.455)\end{array}$ \\
\hline $\begin{array}{l}\text { First stage: } \\
\text { Excluded instruments: }\end{array}$ & & & & & \\
\hline $\begin{array}{l}\text { Lagged employment } \\
\text { protection }\end{array}$ & $\begin{array}{l}0.877^{* * *} \\
(0.085)\end{array}$ & $\begin{array}{l}0.7893^{* * *} \\
(0.0864)\end{array}$ & $\begin{array}{l}0.7728^{* * *} \\
(0.0872)\end{array}$ & $\begin{array}{l}0.8660^{* * *} \\
(0.0908)\end{array}$ & $\begin{array}{l}0.8365^{* * *} \\
(0.093)\end{array}$ \\
\hline $\begin{array}{l}\text { Government (left) } \\
\text { composition }\end{array}$ & $\begin{array}{l}0.0004 * \\
(0.002)\end{array}$ & $\begin{array}{l}0.0004^{* *} \\
(0.002)\end{array}$ & $\begin{array}{l}0.0004 * \\
(0.002)\end{array}$ & $\begin{array}{l}0.0004 * \\
(0.002)\end{array}$ & $\begin{array}{l}0.0003 \\
(0.002)\end{array}$ \\
\hline $\begin{array}{l}\text { Partial R-squared of excluded } \\
\text { instruments }\end{array}$ & 0.6065 & 0.5387 & 0.5217 & 0.5720 & 0.5432 \\
\hline Weak Identification F test & 0.0064 & 0.0068 & 0.0061 & 0.0064 & 0.0075 \\
\hline Hansen J statistic & 0.7150 & 0.8469 & 0.8589 & 0.6875 & 0.7408 \\
\hline Observations & 389 & 405 & 399 & 347 & 341 \\
\hline R-squared & 0.464 & 0.387 & 0.404 & 0.452 & 0.473 \\
\hline Number of countries & 23 & 28 & 28 & 23 & 23 \\
\hline
\end{tabular}

Robust standard errors in parentheses, ${ }^{* * *} p<0.01,{ }^{* *} p<0.05,{ }^{*} p<0.1$.

of market imperfections and market power. The empirical evidence suggests that both opposing views may be at work, thereby offsetting each other.

Among our control variables, first, the effect of investment and tertiary education are significant in most cases. Second, it appears that the real effective exchange rate matters. Countries with overvalued currencies experience below average growth rates of G.D.P. per capita. Third, government consumption (excluding investment spending or spending on social transfers for instance) has a significant negative effect on growth. This is consistent with the findings in the literature: government consumption not including social 
OUP UNCORRECTED PROOF-FIRST PROOF, 8/3/2016, SPi

Crisis Management and Economic Growth in the Eurozone

Table 2.3. Estimation Results (O.L.S.): Five-year Averages and Cross-section

\begin{tabular}{|c|c|c|}
\hline & $\begin{array}{c}\text { (1) } \\
\text { Five-year average } \\
\text { fixed effect model }\end{array}$ & $\begin{array}{c}(7) \\
\text { Cross-section model }\end{array}$ \\
\hline Initial G.D.P. per capita level & - & $\begin{array}{l}-0.0001^{* *} \\
(0.000)\end{array}$ \\
\hline Investment G.D.P. ratio & $\begin{array}{l}0.343^{* *} \\
(0.135)\end{array}$ & $\begin{array}{l}0.1471^{* *} \\
(0.068)\end{array}$ \\
\hline $\begin{array}{l}\text { Tertiary education/total } \\
\text { population }\end{array}$ & $\begin{array}{l}3.639^{* * *} \\
(0.882)\end{array}$ & $\begin{array}{l}0.2345 \\
(0.908)\end{array}$ \\
\hline Real effective exchange rate & $\begin{array}{l}-0.035^{* * *} \\
(0.012)\end{array}$ & $\begin{array}{l}0.0210 \\
(0.019)\end{array}$ \\
\hline Working population growth & $\begin{array}{r}-0.652 \\
(0.500)\end{array}$ & $\begin{array}{l}0.2870 \\
(0.367)\end{array}$ \\
\hline $\begin{array}{l}\text { Government consumption } \\
\text { G.D.P. ratio }\end{array}$ & $\begin{array}{r}-0.410^{*} \\
(0.233)\end{array}$ & $\begin{array}{c}-0.0770 \\
(0.062)\end{array}$ \\
\hline Real retirement age & $\begin{array}{r}-0.040 \\
(0.268)\end{array}$ & $\begin{array}{l}-0.1159^{* *} \\
(0.045)\end{array}$ \\
\hline Government effectiveness & $\begin{array}{c}1.663 \\
(1.062)\end{array}$ & $\begin{array}{l}0.1226 \\
(0.560)\end{array}$ \\
\hline Employment protection & $\begin{array}{c}0.941 \\
(1.634)\end{array}$ & $\begin{array}{c}-0.1032 \\
(0.251)\end{array}$ \\
\hline Product market protection & $\begin{array}{r}-0.602 \\
(0.570)\end{array}$ & $\begin{array}{c}-0.6953 \\
(0.714)\end{array}$ \\
\hline Crisis & $\begin{array}{l}-1.503^{* * *} \\
(0.424)\end{array}$ & \\
\hline Observations & 91 & 32 \\
\hline Number of countries & 32 & 32 \\
\hline R-squared & 0.754 & 0.427 \\
\hline
\end{tabular}

Robust standard errors in parentheses.

*** $\mathrm{p}<0.01,{ }^{* *} \mathrm{p}<0.05,{ }^{*} \mathrm{p}<0.1$.

security spending is considered to be unproductive and thus is negatively associated with real growth.

Finally, we also estimated the model using five-year averages (column (1) in Table 2.3) and a cross-section (column (2) in Table 2.3). The results in Table 3 confirm the previous results. Investments in physical and human capital are significant driving forces of economic growth in the medium and long run. In contrast, no significant effect can be detected of rigidities in labour and product markets on long-term economic growth.

\subsection{Survey of the Literature}

Many econometric studies have been performed measuring the impact of labour and output market rigidities on economic growth (and on productivity growth). In general, econometric studies involving developed countries (mainly O.E.C.D. countries) find weak and often insignificant 
OUP UNCORRECTED PROOF-FIRST PROOF, 8/3/2016, SPi

\section{Paul De Grauwe and Yuemei Ji}

effects of measures of rigidity on economic growth. This is especially the case with measures of labour market regulation for which little evidence exists of any impact on economic growth in the O.E.C.D. countries. This is confirmed by a recent study by the I.M.F. (2015) that could not find a significant effect of employment protection on productivity growth in a sample of industrialized countries (see also Babecki and Campos, 2011). Older studies found mixed evidence. Nickell and Layard (1999) found a positive association between employment protection and productivity per capita, using cross-country variation only. Belot et al. (2007) used a richer data-set, including timevarying indicators of employment protection and legislation, and found that there is an inverse U-shaped relationship between employment protection and growth.

Whereas the previous studies looked at the macroeconomic effects of labour market regulation on economic growth (or productivity growth), Bassanini, Nunziata and Venn (2009) used industry-level data to analyze the relationship between employment protection and productivity growth. These authors found that employment protection legislations have a depressing impact on productivity growth in industries where layoff restrictions are more likely to be binding. It is unclear, however, how large these sectoral effects are when we aggregate them to the economy as a whole.

The empirical evidence of the effect of product market regulation on economic growth confirms the theoretical uncertainty about this effect that we noted in the Section 2.3 (see Aghion et al., 2009). Some econometric evidence has been found that lower product market regulations increase economic growth (Nicoletti and Scarpetta, 2003; O.E.C.D., 2015). What is striking in these studies, however, is that these estimates are not very robust. Typically, researchers present a large number of different specifications and definitions and produce only a few significant results. In Nicoletti and Scarpetta (2003), out of seventeen estimated coefficients of product market regulation variables, only three are significant (see also I.M.F., 2015).

The previous studies were econometric analyses. The O.E.C.D. has performed other empirical studies that simulate the effects of labour and product market deregulations on economic growth. Two approaches have been used: the first consists of taking some of the significant estimated coefficients of market regulation found in the literature and applying these to many countries (see, e.g., De Mello and Padoan, 2010; Barnes et al., 2011; Bouis and Duval, 2011). Sometimes it is not even estimated coefficients that are used, but 'calibrations by assumption' (Barnes et al., 2011). This typically produces complicated graphs showing how deregulation increases economic growth. It should be borne in mind that these simulations use only a small number of estimated coefficients that come from regression exercises 
in which most estimated coefficients of market regulation variables are insignificant.

A second approach also has been popular: this is to use a macroeconomic model of the D.S.G.E. type and to simulate the effect of deregulation on output (European Central Bank, 2015; Eggertsson et al., 2014; Cacciatore et al., 2012). Invariably these simulations find that deregulation of labour and output markets lead to increases in output. ${ }^{3}$ The problem with this approach is that the simulations just confirm a priori beliefs. To give an example, in most D.S.G.E. models unemployment is voluntary, that is results from a decision of individual agents to take more leisure time. Structural reforms are then interpreted as an intervention that changes the relative price of leisure versus labour, that is makes the former more expensive (e.g. by reducing unemployment benefits). As a result, agents will take less leisure time and decide to work longer. Lo and behold, output will increase.

In addition, most D.S.G.E. models used in the simulations are based on calibrations. They are not to be interpreted as empirical evidence. Unfortunately, quite often these simulations are interpreted as providing empirical evidence of how structural reform boosts economic growth.

A striking observation one can make is that econometric studies encompassing both developed and developing countries tend to find significant effects of labour and output market regulations on economic growth. A typical example is a study of the World Bank (Loayza et al., 2004). This study finds that a deregulation of output markets in the developing countries to the mean level achieved in the O.E.C.D. countries would increase economic growth by up to $1.4 \%$ per year.

One may ask the question of why the econometric evidence involving both developing and developed countries tends to be stronger than the evidence about developed (O.E.C.D.) countries alone? The main reason probably is that the developed countries have relatively low levels of regulation of product markets compared with developing countries. This is made clear in Figure 2.5, which shows a measure of product market regulation as computed by the World Bank. It can be seen that within the O.E.C.D. countries the level and the variation of product market regulation is very low compared with that of developing countries.

This implies that once countries have reached the level of regulation achieved in O.E.C.D. countries, few additional gains can be made in terms of increased productivity and growth. Put differently, moving from the very

3 It should be noted that the Eggertson et al. study finds that this is the case in normal times, but not during recessions. Structural reforms during recessions make the recession worse. These authors conclude that during recessions and in the absence of the appropriate monetary stimulus, reforms fuel expectations of prolonged deflation, increase the real interest rate, and depress aggregate demand'. 
OUP UNCORRECTED PROOF-FIRST PROOF, 8/3/2016, SPi

Paul De Grauwe and Yuemei Ji

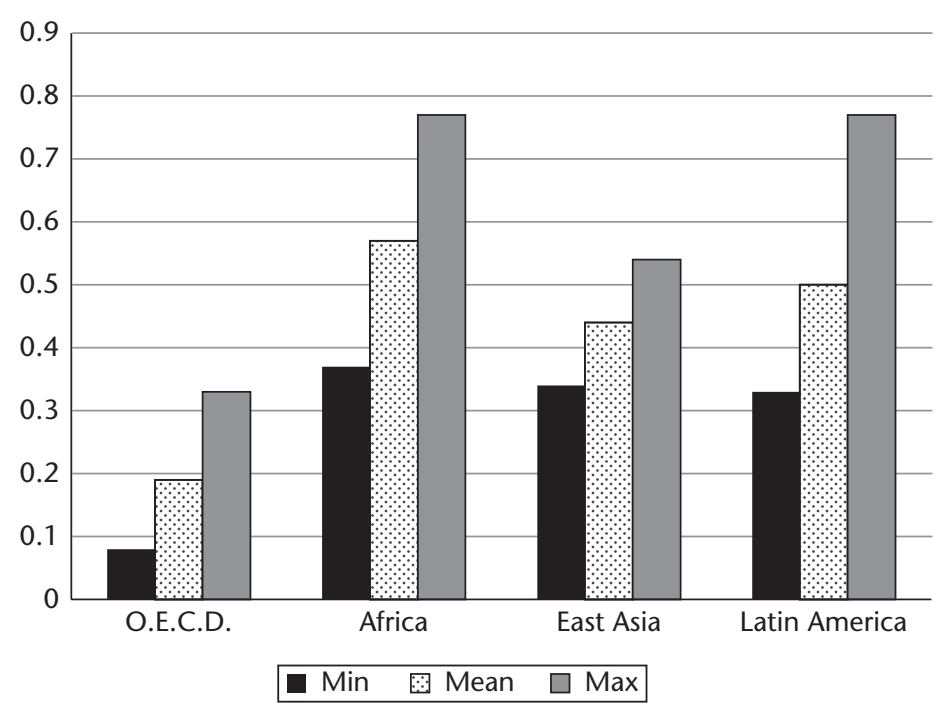

Figure 2.5. Product Market Regulation.

Source: Loayza et al. (2004).

high levels of regulation observed in developing countries towards the low levels reached in the O.E.C.D. countries produces important and significant gains. These gains, however, tend to disappear when the levels of regulation have reached those observed in the O.E.C.D. countries. There is then also very little point in trying to reduce these levels even further.

\subsection{Growth and Macroeconomic Imbalances}

In Sections 2.1-2.4 we argued that stagnation in the G.D.P. of the Eurozone since 2008 has little to do with structural rigidities. In other words it is mostly unrelated to the supply side of the Eurozone countries. In this section we argue that stagnation of the Eurozone during 2008-14 is related to asymmetry in macroeconomic adjustment to external imbalances that has been pursued in the Eurozone since the start of the sovereign debt crisis.

Prior to the crisis, the Southern European countries (including Ireland) accumulated current account deficits, whereas the Northern Eurozone countries ${ }^{4}$ built up current account surpluses. As a result, the Southern countries became the debtors and the Northern countries the creditors in the system (see Figure 2.6). This forced the Southern countries hit by sudden

4 We define Northern Eurozone countries to be Austria, Belgium, Finland, Germany, and the Netherlands. 
OUP UNCORRECTED PROOF-FIRST PROOF, 8/3/2016, SPi

Crisis Management and Economic Growth in the Eurozone

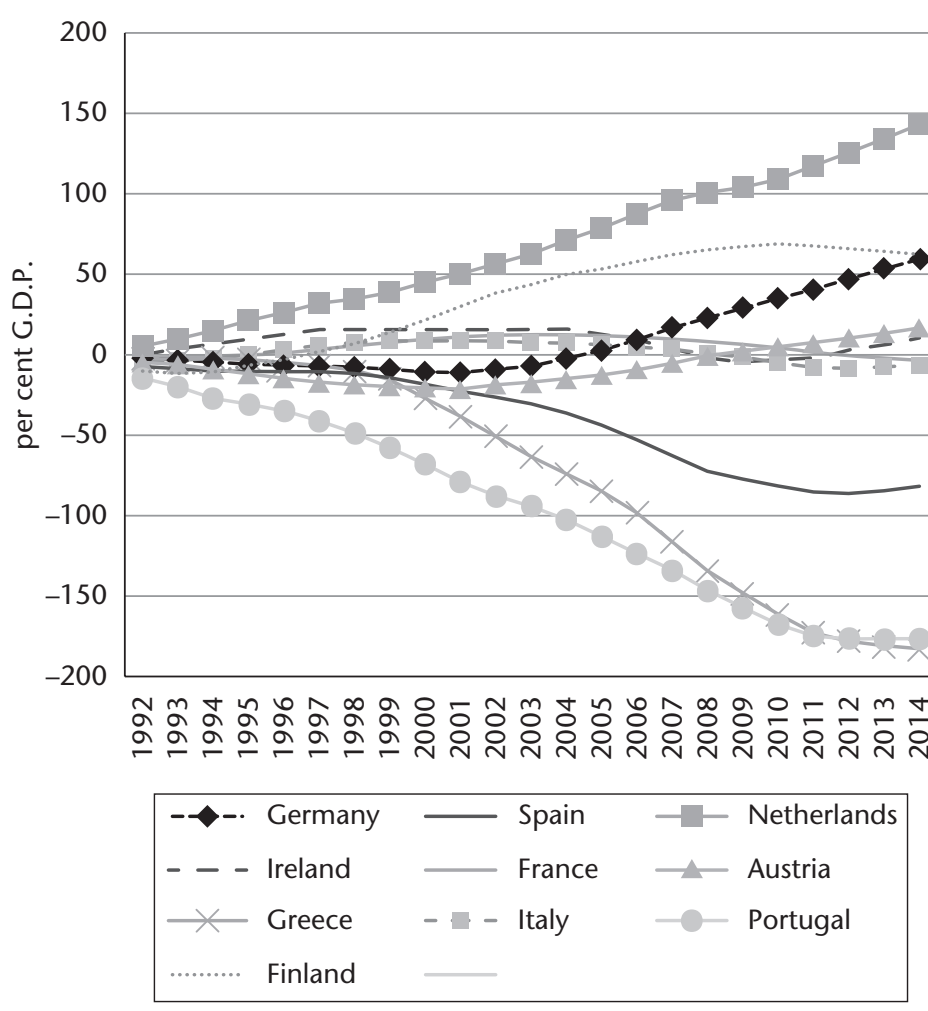

Figure 2.6. Cumulated Current Accounts.

Source: European Commission, Ameco.

liquidity stops to beg the Northern ones for financial support. The latter reluctantly did do so, but only after imposing tough austerity programmes pushing these countries into quick and deep spending cuts and intense recessions.

As a result, the creditor nations in the Eurozone ruled and pushed austerity as the instrument to safeguard the interest of these nations. Another approach would have been possible and could have guided the conduct of macroeconomic policies in the Eurozone. This alternative approach is based on the view that the responsibilities for the current account imbalances are shared between the creditor and debtor nations. The debtor nations took on too much debt and are responsible for that. The creditor nations extended too much credit and are thus equally responsible for the imbalances. For every reckless debtor there must be a reckless creditor. This symmetric view, however, has not prevailed in relations between the creditor and debtor nations of the Eurozone. The former have been viewed as having followed virtuous policies and the latter as having followed foolish ones. As a result, the debtor nations have been forced to bear the full brunt of the adjustment. 


\section{OUP UNCORRECTED PROOF-FIRST PROOF, 8/3/2016, SPi}

Paul De Grauwe and Yuemei Ji

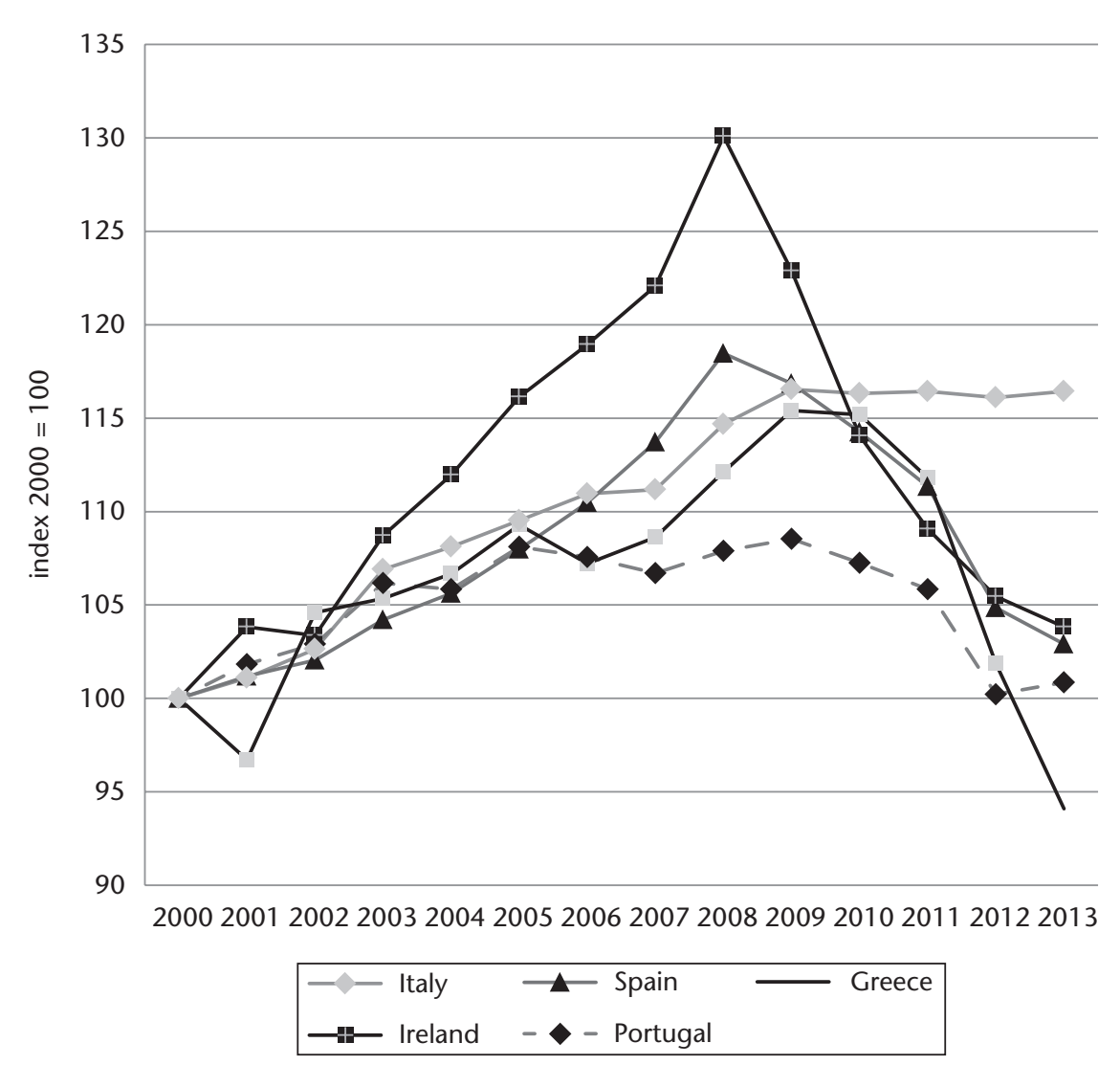

Figure 2.7. Relative Unit Labour Costs in Debtor Countries Eurozone. Source: European Commission, Ameco.

This led to an asymmetric process where most of the adjustment has been done by the debtor nations. In the absence of the option to devalue, the debtor countries have been forced to reduce wages and prices relative to the creditor countries (an 'internal devaluation') without compensating wage and price increases in the creditor countries ('internal revaluations'). This has been achieved by intense austerity programmes in the South, whereas in the North no compensating stimulus has been imposed.

In Figure 2.7, we show some evidence about the nature of this asymmetry. The Figure shows the evolution of the relative unit labour costs ${ }^{5}$ of the debtor countries (where we use the average over the 1970-2010 period as the base period). Two features stand out. First, from 1999 until 2008-9, one observes

5 The relative unit labour cost of a country is defined as the ratio of the unit labour costs of that country and the average unit labour costs in the rest of the Eurozone. An increase in this ratio 
OUP UNCORRECTED PROOF-FIRST PROOF, 8/3/2016, SPi

Crisis Management and Economic Growth in the Eurozone

a strong increase of these countries' relative unit labour costs. Second, since 2008-9 quite dramatic turnarounds of the relative unit labour costs have occurred (internal devaluations) in Ireland, Spain, and Greece, and to a lesser extent in Portugal and Italy.

These internal devaluations have come at a great cost in terms of lost output and employment in the debtor countries mainly because the expenditure-reducing effects of these internal devaluations were more intense than the expenditure switching (competitiveness) effects.

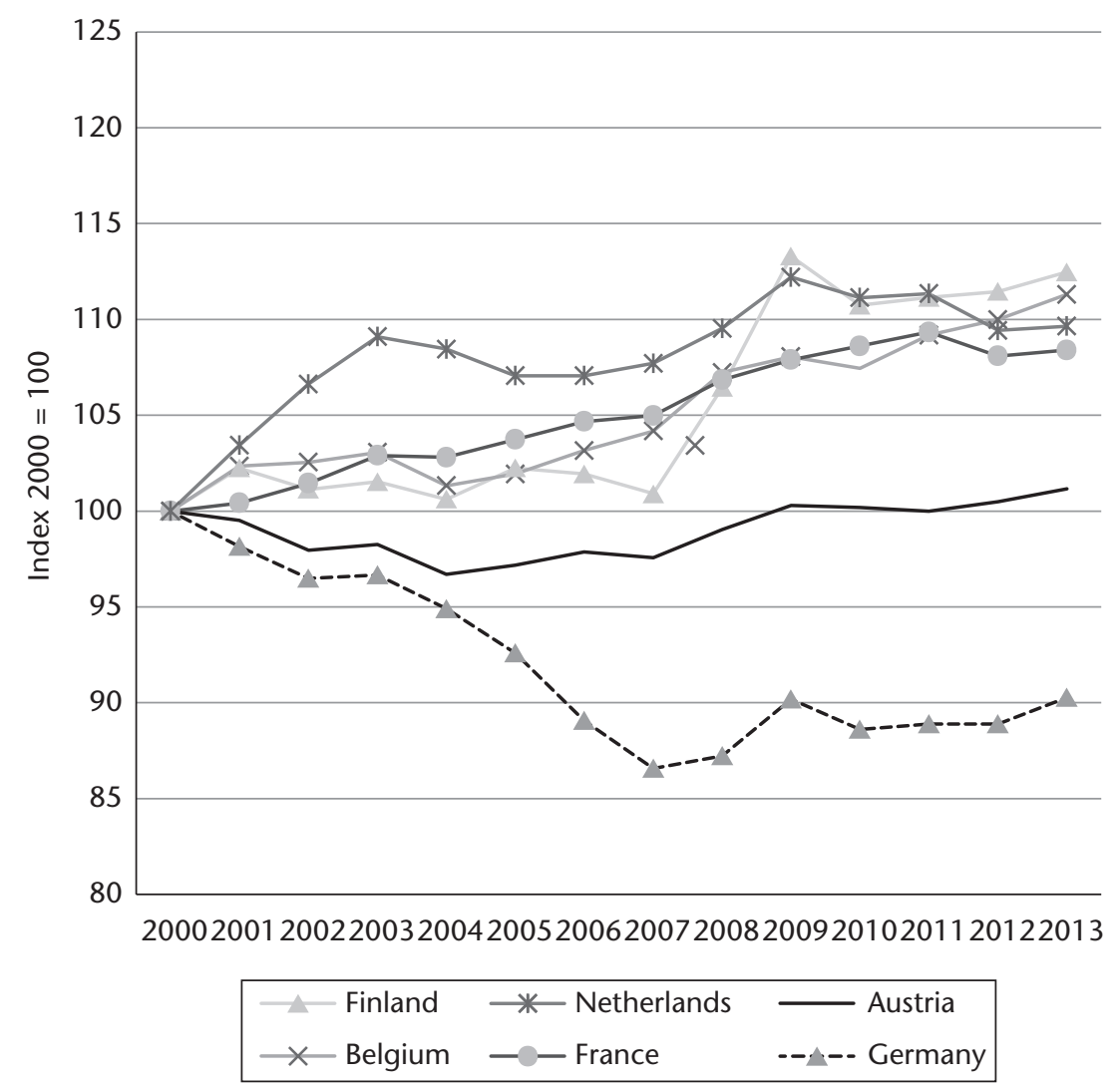

Figure 2.8. Relative Unit Labour Costs in Creditor Countries Eurozone. Source: European Commission, Ameco databank.

indicates that the country in question has seen its unit labour costs increase faster than in the rest of the Eurozone, and vice versa. The relative unit labour costs are computed using the average of the other Eurozone countries. The weights to compute this average, however, are specific to each country as they depend on the shares of trade flows. For example, in the Dutch relative unit labour cost, Germany has a share that is larger than the share of Germany in the Spanish relative unit labour costs. Thus these indices do not have to be symmetrical. 
OUP UNCORRECTED PROOF-FIRST PROOF, 8/3/2016, SPi

Paul De Grauwe and Yuemei Ji

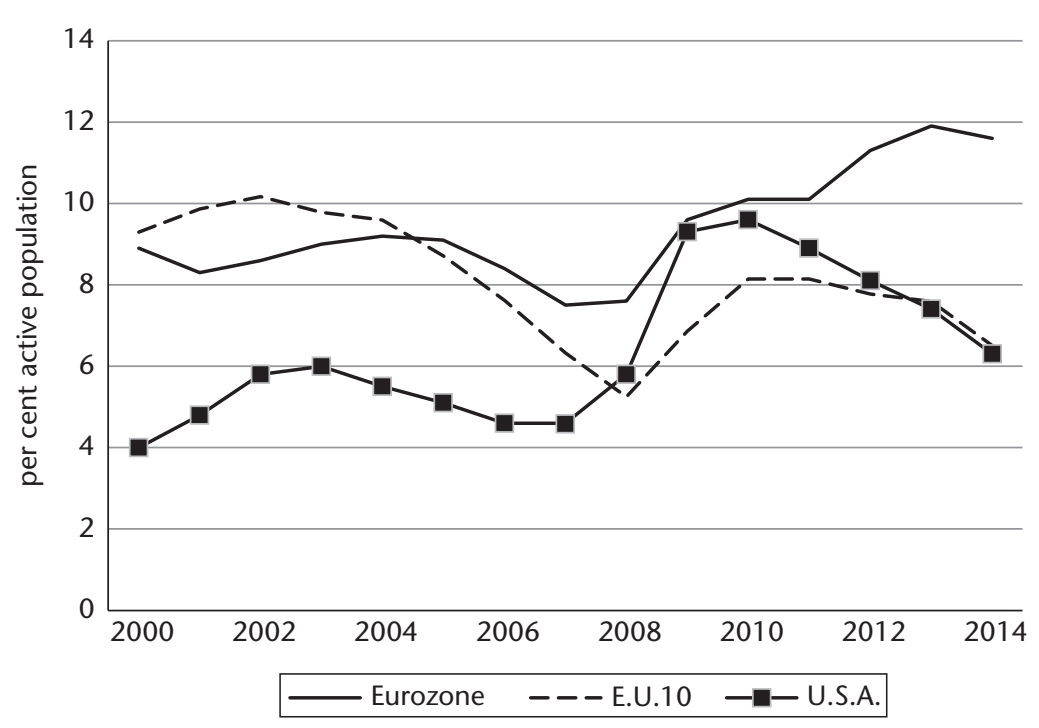

Figure 2.9. Unemployment Rate in the Eurozone, E.U.10 and U.S.A.

Source: European Commission, Ameco databank.

Is there evidence that such a process of internal revaluations has been going on in the surplus countries? The answer is given in Figure 2.8, which presents evolution of the relative unit labour costs in the creditor countries. One observes that since 2008-9 there has been very little movement in these relative unit labour costs in these countries.

Thus, one can conclude that at the insistence of the creditor nations, the burden of the adjustments to the imbalances in the Eurozone has been borne almost exclusively by the debtor countries in the periphery. This has created a deflationary bias that explains why the Eurozone has been pulled into a double-dip recession in 2012-13, and why real G.D.P. has stagnated since 2008 , in contrast with what has happened in the non-Euro E.U. countries and in the U.S.A. It also helps to explain why the unemployment rate increased from $8 \%$ in 2008 to close to $12 \%$ in 2014, whereas in the E.U.10 and in the U.S.A. the unemployment rate started to decline significantly from 2010 (see Figure 2.9).

The deflationary forces to which the Eurozone was subjected as a result of the asymmetric adjustment policies led to two other effects. The first was to turn the current account deficit that existed in 2008 into a surplus of close to 3\% of G.D.P. in 2014 (Figure 2.10). As the debtor nations were forced into austerity, spending declined. The latter was not offset by increased spending in the creditor nations as these nations aimed at maintaining current account surpluses. Thus, the Eurozone adjustment process in all countries consisted of saving more, pushing the current account into a significant surplus. 
OUP UNCORRECTED PROOF-FIRST PROOF, 8/3/2016, SPi

Crisis Management and Economic Growth in the Eurozone

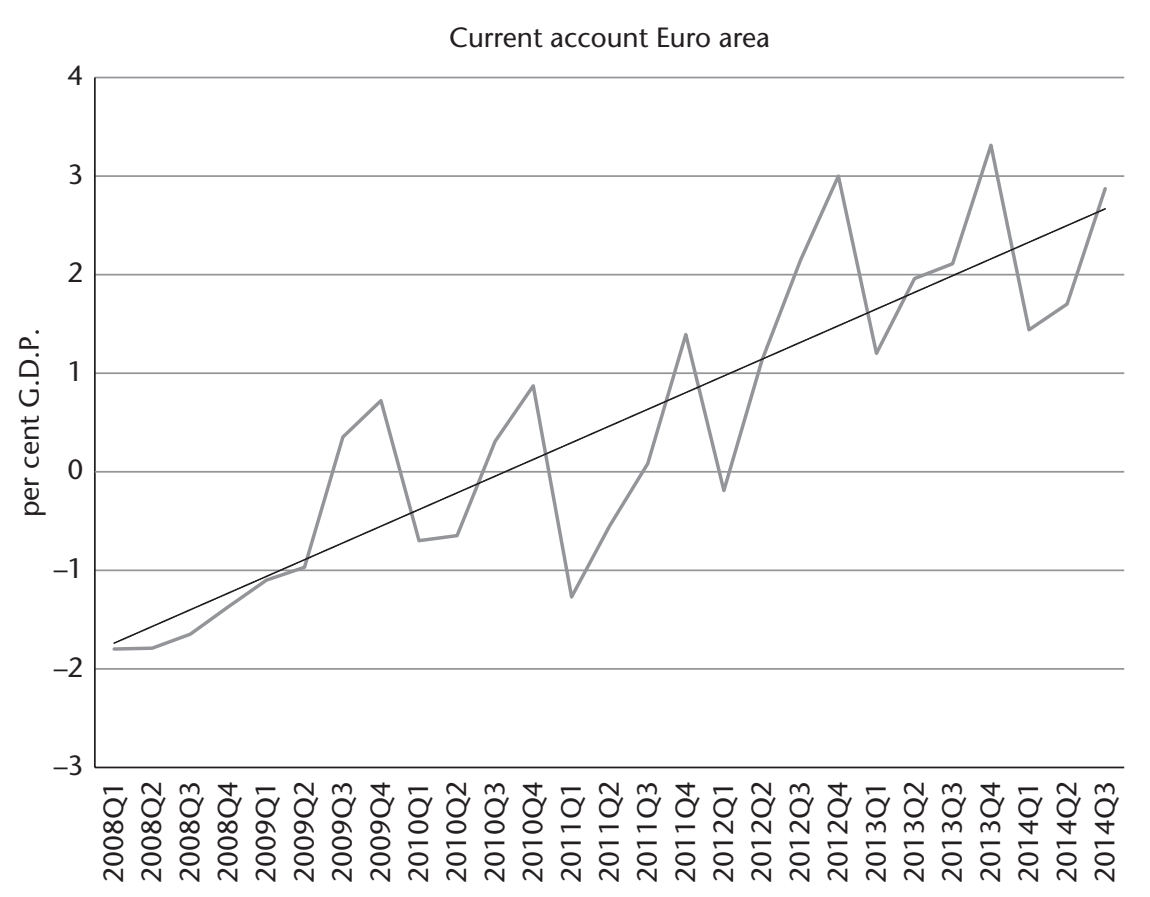

Figure 2.10. Current Account Euro Area.

Source: European Commission, Ameco databank.

The second effect of the deflationary dynamics produced by an asymmetric adjustment process was a sharp decline in inflation, which at the end of 2014 became negative in the Eurozone as a whole. We show this in Figure 2.11, in which we compare the rate of inflation in the Eurozone and the U.S.A. It is striking to find that while the U.S.A. seems to have stabilized its inflation rate around a value of $1.5 \%$, this is not the case in the Eurozone where we observe a continuous decline of inflation since 2011, until it became negative in December 2014.

From the preceding analysis one can conclude that all the phenomena associated with the secular stagnation hypothesis are present in the Eurozone in a significantly more intense manner than they are in the U.S.A. and the other E.U. countries. Increased attempts to save, triggered by external imbalances (and debt accumulation), and lack of an exchange rate instrument to rebalance the economies of the debtor nations, drove inflation into negative territory. This in turn prevented the real interest rate from declining further so as to equilibrate savings and investments. As a result, the Eurozone seems to be stuck in a low-growth-high-unemployment equilibrium.

It is interesting to make a historic parallel here. During the 1930s a number of European countries decided to stay on gold and to keep their exchange 
OUP UNCORRECTED PROOF-FIRST PROOF, 8/3/2016, SPi

Paul De Grauwe and Yuemei Ji

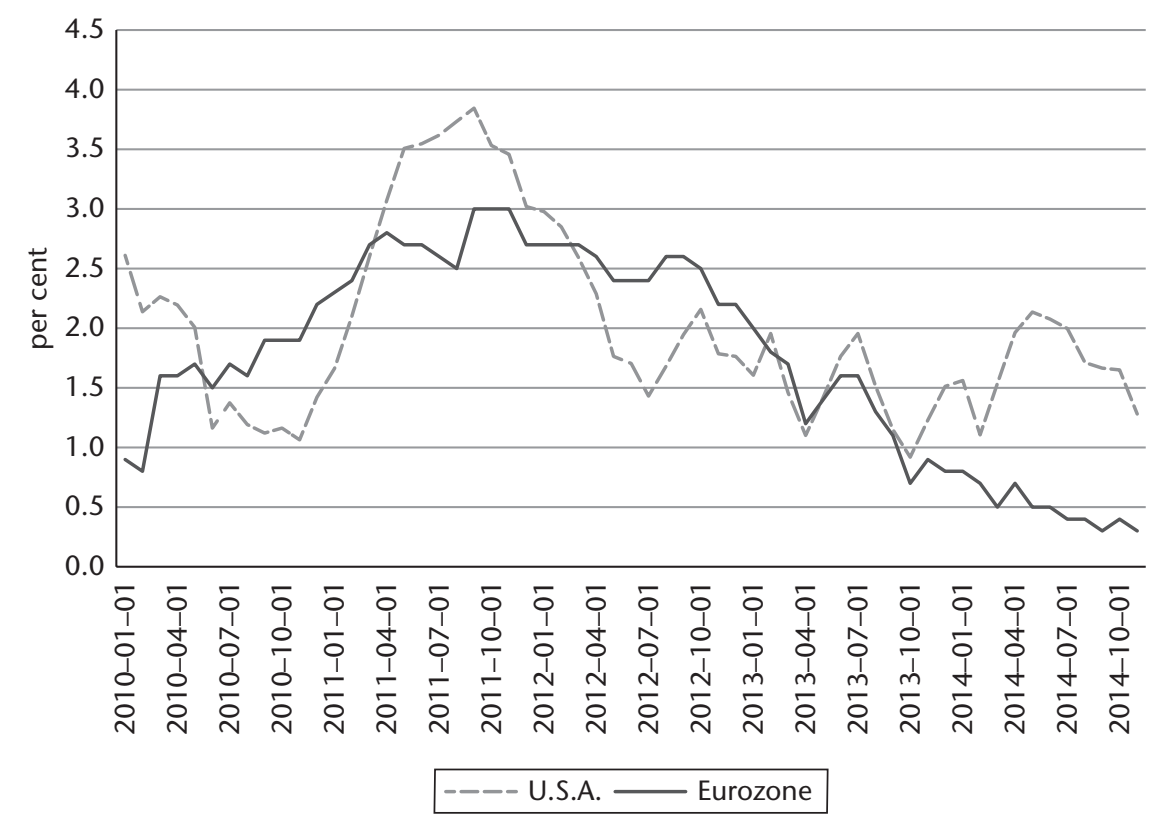

Figure 2.11. Inflation in the U.S.A. and the Eurozone. Source: ECB.

rates fixed. This forced these countries into deflationary demand policies aimed at restoring balance of payments equilibrium. As a result, they failed to recover and performed significantly worse than the countries that went off gold and devalued their currencies (see Eichengreen, 1992). Something very similar has happened in the Eurozone since the Great Recession. ${ }^{6}$

The nature of macroeconomic policies in the Eurozone is illustrated in Figure 2.12, which shows the production possibility frontier. These policies focused on structural reform (supply side policies) aimed at shifting the production possibility frontier of the Eurozone outward. Our empirical analysis suggests that it is unclear whether these policies actually worked to generate such a positive shift. At the same time the austerity policies that were applied throughout the Eurozone reduced aggregate demand. As a result, effective production (shown by the dot inside the production possibility frontier) declined. The austerity policies had the effect of reducing public investment and spending for education. As a result, the two main drivers of economic growth, physical and human capital accumulation were affected negatively. Thus it is more likely that the macroeconomic policies pursued in the Eurozone had the effect of shifting the production possibilities frontier

\footnotetext{
${ }^{6}$ See also Eichengreen and O'Rourke (2009).
} 
OUP UNCORRECTED PROOF-FIRST PROOF, 8/3/2016, SPi

Crisis Management and Economic Growth in the Eurozone

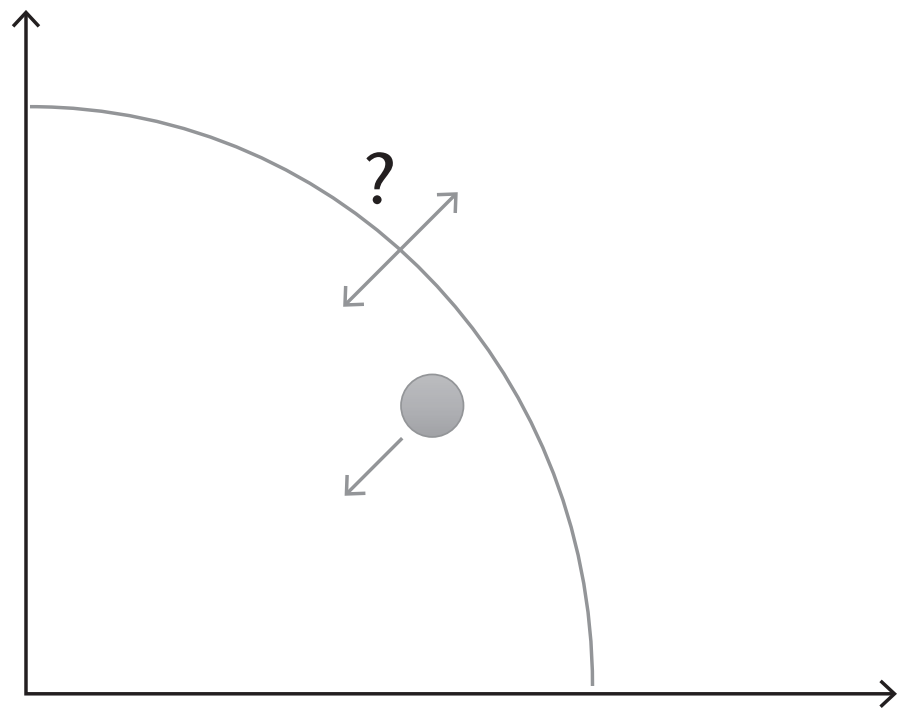

Figure 2.12. Production Possibility Frontier.

downwards, together with a decline in effective production (see Blanchard and Leigh, 2013).

\subsection{What Should Be Done?}

All this leads to the question of what to do today, in 2016? As stressed by many participants in the debate concerning secular stagnation (see Teulings and Baldwin, 2014; Summers, 2014), the policy mix to lift countries from the low growth and high unemployment equilibrium is a mix of monetary and fiscal expansion.

The E.C.B. decided to do its part, albeit rather late, when it decided to start its Q.E. programme in January 2015. Although this programme looks quite spectacular, it should not be forgotten that the E.C.B. will be restoring the money base to its pre-crisis growth path. This is made clear in Figure 2.13, which contrasts the balance sheets of the E.C.B. with those of the U.S. Fed. The contrast since 2012 is spectacular. To stimulate the U.S. economy, the Fed engaged in a dramatic increase of its balance sheet. During the same time, when the Eurozone turned back in a double-dip recession, the E.C.B. allowed its balance sheet to contract by $€ 1$ trillion. Quite a surprising policy choice. The announced Q.E. programme of $€ 1$ trillion will bring the money base back on track, not more than that. 


\section{OUP UNCORRECTED PROOF-FIRST PROOF, 8/3/2016, SPi}

\section{Paul De Grauwe and Yuemei Ji}

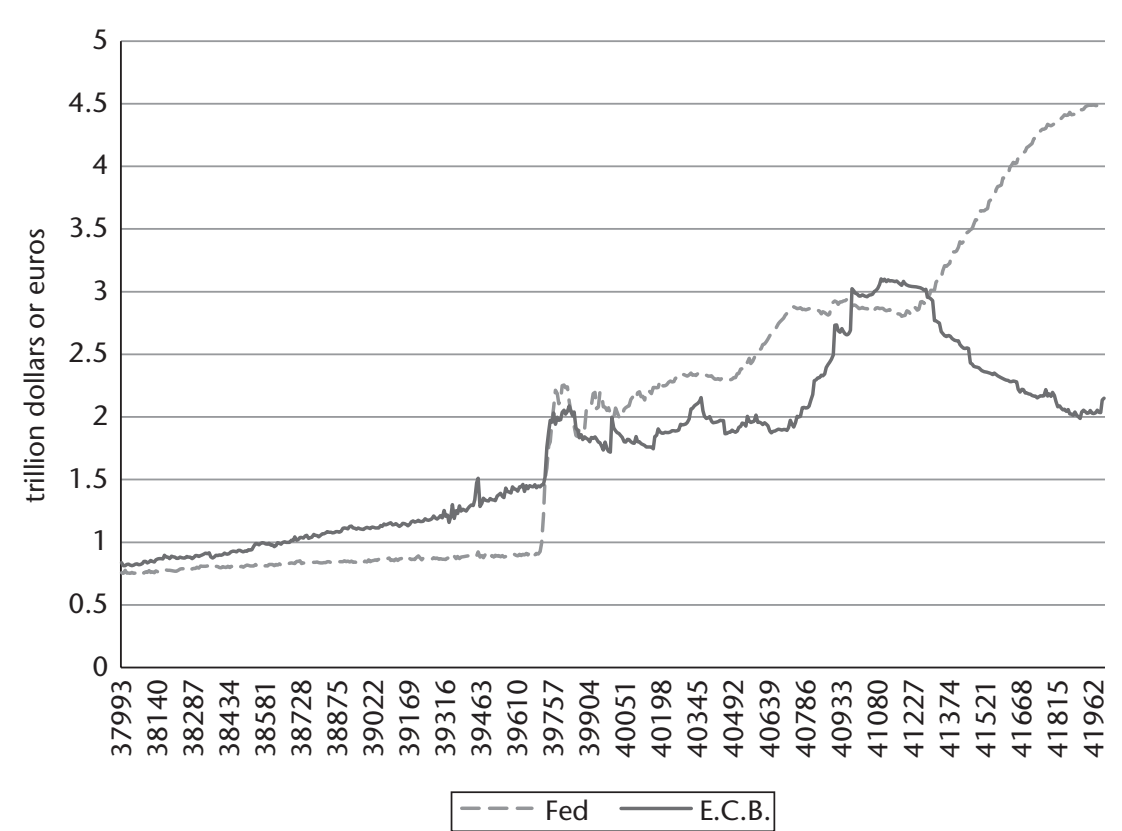

Figure 2.13. Balance Sheet Fed and E.C.B. (2004-14).

Source: E.C.B. and Federal Reserve.

It is now generally recognized that when the economy is in a liquidity trap, monetary policy is insufficient to stimulate aggregate demand, and that fiscal policies have to take the brunt of demand stimulus.

Governments of the Eurozone, in particular in the Northern member countries now face historically low long-term interest rates. The German government, for example, can borrow at less than $1 \%$ at a maturity of ten years. These historically low interest rates create a window of opportunities for these governments to start a major investment programme. Money can be borrowed almost for free, while in all these countries there are great needs to invest in the energy sector, the public transportation systems, and the environment.

This is therefore the time to reverse the ill-advised decisions made since 2010 to reduce public investments, as illustrated in Figure 2.14. This can be done at very little cost. The country that should lead this public investment programme is Germany. There are two reasons for this. First, as we argued earlier, the asymmetric nature of the macroeconomic adjustment programmes within the Eurozone unnecessarily magnified the cost of these programmes in the debtor nations, and is responsible for the stagnation of the Eurozone since 2008. Second, public investments as a per cent of G.D.P. in Germany are among the lowest of all Eurozone countries. In 2013 public investment 


\section{OUP UNCORRECTED PROOF-FIRST PROOF, 8/3/2016, SPi}

Crisis Management and Economic Growth in the Eurozone

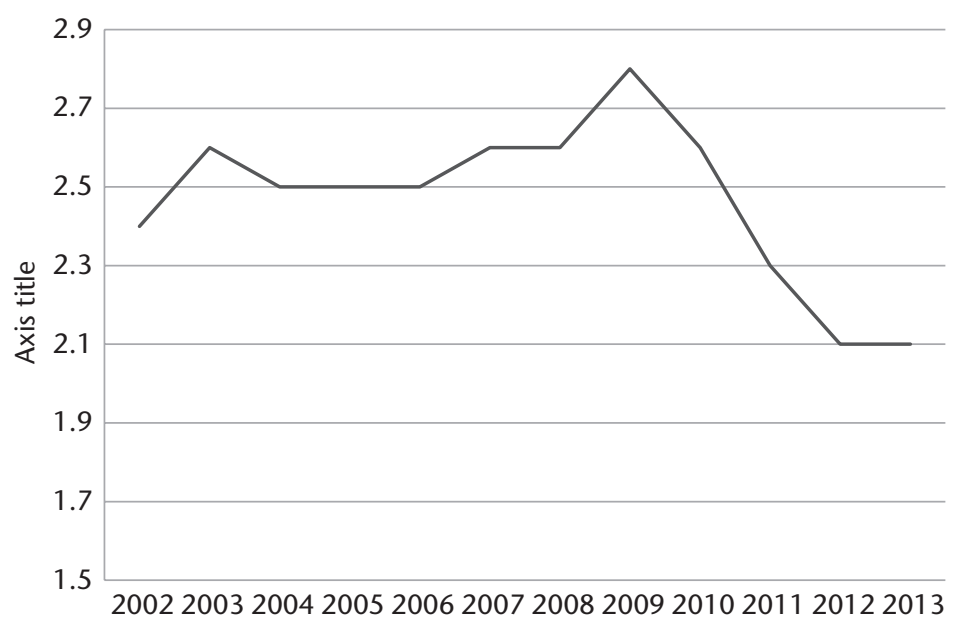

Figure 2.14. Public Investment in the Eurozone.

Source: Eurostat.

in German amounted to a bare 1.6\% of G.D.P. versus 2.3\% in the rest of the Eurozone (see also Fratzscher, 2014, on this).

Such a public investment programme would do two things. First, it would stimulate aggregate demand in the short run and help to pull the Eurozone out of its stagnation. Second, in the long run it would help to lift the longterm growth potential in the Eurozone.

The prevailing view in many countries is that governments should not increase their debt levels lest they put a burden on future generations. The truth is that future generations inherit not only the liabilities but also the assets that have been created by the government. Future generations will not understand why these governments did not invest in productive assets that improve these generations' welfare, while present-day governments could do so at historically low financing costs.

There is a second factor that prevents European policymakers from using a large government investment programme to lift the Eurozone from its stagnation. These policymakers continue to believe that the stagnation since 2008 is a result of structural rigidities in the Eurozone. Thus the problem of stagnation is seen as originating exclusively from the supply side. In this view structural reforms (together with austerity) are the answer.

We have shown evidence that structural rigidities in the labour and product markets have insignificant effect on economic growth. As a result these rigidities cannot be seen as the primary cause of the Eurozone stagnation since 2008. It is time policymakers face this truth and start following policies 
OUP UNCORRECTED PROOF-FIRST PROOF, 8/3/2016, SPi

\section{Paul De Grauwe and Yuemei Ji}

that work. This will have to come mainly from fiscal programmes aimed at boosting investment.

\subsection{Conclusion}

Macroeconomic policies pursued since the financial crisis in the Eurozone have not been evidence-based. Supply side policies ('structural reforms') have been at the centre of policy-thinking in the Eurozone and member countries have been forced to implement such supply side policies. In this chapter, we have provided evidence against the view that supply side policies boost economic growth. In some cases the evidence even suggests that these policies might reduce economic growth. This is particularly the case with the forced breakdown of employment protection, which is likely to reduce investment in human capital.

Thus it appears that macroeconomic policies rather than being evidencebased have been ideology-based. This ideology claims that flexibility in labour and product markets should be pursued under all circumstances. The evidence that this will lead to more growth is extremely thin.

In contrast, the strong empirical evidence that investment in physical and human capital is key to economic growth has not been used. On the contrary, in the name of austerity and a phobia vis-à-vis government debt, a decline in public investment was set in motion endangering the long-term potential of the Eurozone. In addition, austerity had the effect of reducing spending for education, thereby reducing the potential for long-term economic growth.

The discussion in this chapter does not imply that no structural reforms are necessary. Some are, even if their implications for economic growth are uncertain. The main structural reform in the labour market consists of eliminating its dual nature. This has been a serious problem in countries like Italy and Spain, in which older workers are fully protected and the newcomers, the young, are not. As a result, the latter face extremely flexible labour contrasts with little protection. This duality in labour contracts has the effect of reducing human capital of the young as both the firms and the young have little incentives to invest in better skills. In addition, this duality leads to important negative social and political effects as a new generation feels it is not really integrated in society. Some steps have been taken in a number of countries (Italy, Spain) with new legislation that promises to do away with this duality. This is done by introducing a unified labour contract for young and old, whereby employment protection is gradually built up for the young that enter the labour market (see Boeri et al., 2013).

The crisis management that was set up in the Eurozone after the eruption of the government debt crisis can be said to be responsible for the economic 
OUP UNCORRECTED PROOF-FIRST PROOF, 8/3/2016, SPi

Crisis Management and Economic Growth in the Eurozone

stagnation experienced by the Eurozone. This crisis management was characterized by two features. One was the asymmetric adjustment to the current account imbalances that forced the deficit countries into intense austerity without a compensating policy of stimulus in the surplus countries. This led to a deflationary bias that created strong collateral damage on investment, both private and public.

The second feature of crisis management was its focus on supply policies. While the overriding macroeconomic problem was an insufficiency of demand, policymakers insisted on fixing the supply side of the economy in the hope that this would spur long-term economic growth. The evidence we have provided in this chapter is that these supply side policies have insignificant, and sometimes even negative effects on long-term economic growth. As a result, together with the negative effects of austerity on investment, it can be concluded that the crisis management in the Eurozone not only exacerbated a demand problem, but also harmed the long-term growth potential of the Eurozone.

\section{Appendix 2.1 Description of the Variables}

\begin{tabular}{|c|c|c|}
\hline Variable & Sources & Note \\
\hline Real growth rate & O.E.C.D. & \\
\hline Investment/ G.D.P. & $\begin{array}{l}\text { World Bank } \\
\text { W.D.I. }\end{array}$ & \\
\hline $\begin{array}{l}\text { Real effective } \\
\text { exchange rate }\end{array}$ & O.E.C.D. & $\begin{array}{l}\text { Measures the competitiveness-weighted relative } \\
\text { consumer prices and unit labour costs for a } \\
\text { country }\end{array}$ \\
\hline $\begin{array}{l}\text { Working population } \\
\text { growth }\end{array}$ & O.E.C.D. & \\
\hline $\begin{array}{l}\text { Government con- } \\
\text { sumption/G.D.P. }\end{array}$ & $\begin{array}{l}\text { Oxford } \\
\text { Economics }\end{array}$ & $\begin{array}{l}\text { Value of government spending on goods and ser- } \\
\text { vices expressed as a share of nominal G.D.P. } \\
\text { This includes things like the public sector's pay- } \\
\text { roll and procurement. It does not include invest- } \\
\text { ment spending or spending on social transfers for } \\
\text { instance }\end{array}$ \\
\hline $\begin{array}{l}\text { Effective retirement } \\
\text { age }\end{array}$ & O.E.C.D. & \\
\hline $\begin{array}{l}\text { Government } \\
\text { effectiveness }\end{array}$ & $\begin{array}{l}\text { Worldwide } \\
\text { governance } \\
\text { indicator }\end{array}$ & \\
\hline $\begin{array}{l}\text { Proportion of tertiary } \\
\text { education }\end{array}$ & $\begin{array}{l}\text { World Bank } \\
\text { education } \\
\text { I.I.A.S.A./V.I.D. } \\
\text { Projection }\end{array}$ & $\begin{array}{l}\text { Proportion of population by educational attain- } \\
\text { ment, age 15-64, total, tertiary }\end{array}$ \\
\hline
\end{tabular}


OUP UNCORRECTED PROOF-FIRST PROOF, 8/3/2016, SPi

Paul De Grauwe and Yuemei Ji

\begin{tabular}{|c|c|c|}
\hline Variable & Sources & Note \\
\hline $\begin{array}{l}\text { Employment } \\
\text { protection } \\
\text { legislation (E.P.L.) }\end{array}$ & O.E.C.D. & $\begin{array}{l}\text { Strictness of employment protection-individual and collec- } \\
\text { tive dismissals (regular contracts) }\end{array}$ \\
\hline $\begin{array}{l}\text { Product market } \\
\text { protection index }\end{array}$ & O.E.C.D. & $\begin{array}{l}\text { A comprehensive and internationally comparable set of indi- } \\
\text { cators that measure the degree to which policies promote } \\
\text { or inhibit competition in areas of the product market where } \\
\text { competition is viable. They measure the economy-wide } \\
\text { regulatory and market environments. The indicators cover } \\
\text { formal regulations in the following areas: state control } \\
\text { of business enterprises; legal and administrative barriers } \\
\text { to entrepreneurship; barriers to international trade and } \\
\text { investment }\end{array}$ \\
\hline $\begin{array}{l}\text { Government cabinet } \\
\text { composition } \\
\text { (left) } \%\end{array}$ & $\begin{array}{l}\text { Comparative } \\
\text { political data }\end{array}$ & $\begin{array}{l}\text { Government composition: cabinet posts of social democratic } \\
\text { and other left parties as a percentage of total cabinet posts. } \\
\text { Weighted by the number of days in office in a given year }\end{array}$ \\
\hline
\end{tabular}

\section{Appendix 2.2 Investment G.D.P. Ratio Regression (fixed effects model)}

\begin{tabular}{|c|c|c|c|c|}
\hline & $\begin{array}{c}(1) \\
\text { Advanced } \\
\text { economies } \\
\text { 1985-2013 }\end{array}$ & $\begin{array}{c}(2) \\
\text { O.E.C.D. } \\
\text { economies } \\
\text { 1998-2013 }\end{array}$ & $\begin{array}{c}(3) \\
\text { Advanced } \\
\text { economies } \\
\text { 1998-2013 }\end{array}$ & $\begin{array}{c}(4) \\
\text { Advanced } \\
\text { economies } \\
\text { 1998-2013 }\end{array}$ \\
\hline Growth & $\begin{array}{c}0.087 \\
(0.063)\end{array}$ & $\begin{array}{l}0.137^{* * * *} \\
(0.045)\end{array}$ & $\begin{array}{c}0.107 * \\
(0.052)\end{array}$ & $\begin{array}{c}0.106 * \\
(0.054)\end{array}$ \\
\hline Real effective exchange rate & $\begin{array}{c}0.028 \\
(0.021)\end{array}$ & $\begin{array}{l}0.041^{\text {*** }} \\
(0.013)\end{array}$ & $\begin{array}{c}0.032 \\
(0.019)\end{array}$ & $\begin{array}{l}0.047^{* * *} \\
(0.016)\end{array}$ \\
\hline Working population growth & $\begin{array}{l}2.330^{* * * *} \\
(0.532)\end{array}$ & $\begin{array}{l}2.072^{\text {*** }} \\
(0.486)\end{array}$ & $\begin{array}{l}2.405^{\text {*** }} \\
(0.551)\end{array}$ & $\begin{array}{l}2.269^{* * *} \\
(0.515)\end{array}$ \\
\hline $\begin{array}{l}\text { Government consumption } \\
\text { G.D.P. ratio }\end{array}$ & $\begin{array}{l}-0.235 \\
(0.175)\end{array}$ & $\begin{array}{r}-0.212^{*} \\
(0.123)\end{array}$ & $\begin{array}{c}-0.187 \\
(0.168)\end{array}$ & $\begin{array}{c}-0.167 \\
(0.162)\end{array}$ \\
\hline Real retirement age & $\begin{array}{c}0.211 \\
(0.178)\end{array}$ & $\begin{array}{c}0.193 \\
(0.193)\end{array}$ & $\begin{array}{c}0.153 \\
(0.175)\end{array}$ & $\begin{array}{c}0.227 \\
(0.168)\end{array}$ \\
\hline Government effectiveness & $\begin{array}{c}-0.152 \\
(1.083)\end{array}$ & $\begin{array}{c}0.417 \\
(0.936)\end{array}$ & $\begin{array}{c}-0.178 \\
(1.061)\end{array}$ & $\begin{array}{r}-0.039 \\
(0.951)\end{array}$ \\
\hline $\begin{array}{l}\text { Tertiary education/total } \\
\text { population }\end{array}$ & $\begin{array}{r}-0.415^{*} \\
(0.206)\end{array}$ & $\begin{array}{r}-0.244^{*} \\
(0.129)\end{array}$ & $\begin{array}{c}-0.242 \\
(0.162)\end{array}$ & $\begin{array}{c}-0.166 \\
(0.144)\end{array}$ \\
\hline Employment protection & $\begin{array}{l}5.707^{* * *} \\
(1.312)\end{array}$ & $\begin{array}{l}4.220^{* * *} \\
(1.187)\end{array}$ & $\begin{array}{l}5.952^{* * *} \\
(1.369)\end{array}$ & $\begin{array}{l}4.382^{* * *} \\
(1.342)\end{array}$ \\
\hline Product market protection & & $\begin{array}{c}0.734 \\
(0.582)\end{array}$ & & $\begin{array}{c}1.109 \\
(0.719)\end{array}$ \\
\hline Observations & 409 & 457 & 365 & 359 \\
\hline R-squared & 0.543 & 0.525 & 0.579 & 0.611 \\
\hline Number of iid & 24 & 32 & 24 & 24 \\
\hline
\end{tabular}

Robust standard errors in parentheses.

*** $\mathrm{p}<0.01,{ }^{* *} \mathrm{p}<0.05,{ }^{*} \mathrm{p}<0.1$. 
OUP UNCORRECTED PROOF-FIRST PROOF, 8/3/2016, SPi

Crisis Management and Economic Growth in the Eurozone

\subsection{References}

Acemoglu, D., (2009), Introduction to Modern Economic Growth, Princeton University Press.

Acemoglu, D., and J. Robinson, (2012), Why Nations Fail: The Origins of Power, Prosperity, and Poverty, Crown Business.

Aghion, P., and P. Howitt, (1998), Endogenous Growth Theory, Cambridge: Mass.: The MIT Press.

Aghion, P., C. Harris, P. Howitt, and J. Vickers (2001), 'Competition, Imitation and Growth with Step-by-Step Innovation', Review of Economic Studies, 2001, 68, 3, 467-92.

Aghion, P., R. Blundell, R. Griffith, P. Howitt, and S. Prantl (2009), 'The Effects of Entry on Incumbent Innovation and Productivity', Review of Economics and Statistics, 2009, 91, 1, 20-32.

Babecky, J., and N. Campos, (2011), Does Reform Work? An econometric survey of the reform-growth puzzle, Journal of Comparative Economics, 39, 140-58.

Barnes, S., R. Bouis, Ph. Briard, S. Dougherty, and M. Eris, (2011), The GDP Impact of Reform: A Simple Simulation Framework, Economics Department Working paper, no. 834, OECD.

Barro, R., and X. Sala-i-Martin, (2003), Economic Growth, MIT Press.

Bassanini, A., L. Nunziata, and D. Venn, (2009), Job protection legislation and productivity growth in OECD countries, Economic Policy, 24, 349-402.

Belot, M. V. K., J. Boone, and J. C. van Ours, (2007), Welfare improving employment protection. Economica, 74, 295, 381-96.

Blanchard, O., and D. Leigh, (2013), Fiscal Consolidation: At What Speed?, VoxEU.org, 3 May.

Boeri, T., P. Garibaldi, and E. R. Moen, (2013), The Economics of Severance Pay, IZA Discussion Papers 7455, Institute for the Study of Labor (IZA).

Bouis, R., and Duval, R., (2011), Raising potential growth after the crisis: a quantitative assessment of the potential gains from various structural reforms in the OECD area and beyond, Economics Department Working Papers, no. 835, OECD.

Cacciatore, M., Duval, R., and Fiori, G., (2012), Short-term gain or pain? A DSGE model-based analysis of the short-term effects of structural reforms in labour and product markets, Economics Department Working paper no. 948, OECD.

De Mello, and Padoan, (2010), Promoting Potential Growth: The Role of Structural Reform, Economics Department Working paper, no. 793, OECD.

European Central Bank (E.C.B.), (2015), Progress with structural reforms across the euro area and their possible impacts, Economic Bulletin, 2.

Eggertsson, G., Ferrero, A., and Raffo, A., (2014), Can Structural reforms help Europe?, Journal of Monetary Economics, 612-22.

Eichengreen, B., (1992), Golden Fetters: The Gold Standard and the Great Depression, Oxford University Press, Oxford.

Eichengreen, B., and K. O'Rourke, (2009), A tale of two depressions: What do the new data tell us? February 2010 update, VoxEU. 
OUP UNCORRECTED PROOF-FIRST PROOF, 8/3/2016, SPi

\section{Paul De Grauwe and Yuemei Ji}

Fratzscher, M., (2014), Die Deutschland-Illusion: Warum wir unsere Wirtschaft überschätzen und Europa brauchen, Hanser.

IMF World Economic Outlook, (2015), Ch. 3, Box 3.5 on The Effects of Structural Reforms on Total Factor Productivity, 104-7.

Loayza, N., A. Oviedo, and L. Serven, (2004), Regulation and Macroeconomic Performance, World Bank.

Nickell, S. J., and Layard, R. (1999), Labour market institutions and economic performance. In: O. Ashenfelter and D. Card (eds.), Handbook of Labour Economics. Amsterdam: North-Holland, 3029-84.

Nicoletti, G., and Scarpetta, S., (2003), Regulation, Productivity and Growth. OECD evidence, Policy Research Working Paper, The World Bank.

O.E.C.D., Going for Growth, (2015), http://www.keepeek.com/Digital-Asset-Manage ment/oecd/economics/economic-policy-reforms-2015_growth-2015-en\#page11.

Summers, L., (2014), Reflections on the New 'Secular Stagnation Hypothesis', VoxEU, October, http://www.voxeu.org/article/larry-summers-secular-stagnation.

Teulings, C., and Baldwin, R., (2014), Secular Stagnation. Facts, Causes and Cures. A new vox ebook, October http://www.voxeu.org/article/secular-stagnation-factscauses-and-cures-new-vox-ebook. 